\title{
THE FREQUENCY OF SALMONELLAE IN WILD DUCKS
}

\author{
T. R. Mitchell AND T. RIDGWELL \\ Department of Microbiology, Fulham Hospital, London
}

SALMONELla infections in wild birds have been described by many workers (Keymer, 1958; Nielsen, 1960; Jennings, 1961; Macdonald, 1965; Faddoul, Fellows and Baird, 1966; Wilson and Macdonald, 1967). Most of the surveys have been limited, however, to the examination of post-mortem material and the isolation rates have varied. In London, Farrant, Phillips and Roger (1964) found salmonellae in 6.15 per cent. of 246 feral pigeons, but Jennings (1961) isolated them from 0.1 per cent. of 734 wild birds and Keymer (1958) from 0.2 per cent. of 460 such birds; these workers examined 1440 specimens in all.

There are few surveys of faecal excretion rates in wild birds. In London, Salmonella typhimurium was recovered from 2.25 per cent. of feral pigeon droppings in Trafalgar Square (Cruickshank and Smith, 1949). During 1966 and 1967, gull faeces from some of the Metropolitan Water Board's installations yielded a 17 per cent. isolation rate of nine different serotypes of salmonellae, including seven different phage-types of $S$. typhimurium (Windle Taylor, 1967). These findings differ from those of Farrant et al., whose isolates were all $S$. typhimurium of the characteristic phage-type 440 but without the 05 antigen.

The object of this study was to determine the faecal excretion rate of salmonellae in freeliving wild ducks. These birds cross large areas of Europe in their annual migrations from the North to their wintering areas in Britain and elsewhere and are a potential health hazard to man.

\section{MATERIALS AND METHODS}

Duck droppings were collected from Barn Elms Reservoir, London, during 1969 and 1970. Most of the specimens were collected in the early morning. Care was taken to obtain fresh specimens from areas where ducks had been observed to have been roosting overnight on the brickwork edge of the reservoir.

The actual number of ducks roosting on the reservoir was between 500 and 1500 in both winters. The three predominant species were tufted duck (Aythya fuligula), pochard (Aythya ferina) and teal (Anas crecca). Smaller numbers of widgeon (Anas penelope) and gadwall (Anas strepera) were also present.

The faeces were suspended in sterile 0.9 per cent. saline to give an approximate dilution of 1 in 20. Within $2 \mathrm{hr}$ a loopful of the saline suspension was inoculated into Rappaport's medium (Rappaport, Konforti and Navon, 1956) and into Selenite F broth; after $24 \mathrm{hr}$ both of these were subcultured on MacConkey bile salt agar, desoxycholate citrate agar (DCA) and Wilson and Blair's bismuth sulphite agar (Oxoid). This range of media was used partly to compare Selenite F with Rappaport's medium, but also to screen for the presence of $S$. typhi for which Rappaport's medium is not suitable.

Salmonellae were identified by the customary biochemical and serological tests. All positive results were confirmed by the Salmonella Reference Laboratory, P.H.L.S., Colindale. Phage-typing was carried out at the Enteric Reference Laboratory, Colindale.

\section{RESULTS}

During two winters (1968/69 and 1969/70), 477 duck droppings found at Barn Elms Reservoir were examined. In the first winter, 307 samples were cultured of which 13 (4.24 per cent.) contained salmonella serotypes; during the second winter 170 samples yielded seven (4.11 per cent.) isolates (table). Most isolations were from the three commonest species

Received 27 Oct. 1970; accepted 10 Dec. 1970.

J. MED. MICROBIOL.-VOL. 4 (1971) 
of duck, pochard, teal and tufted duck. There was little difference in the carrier rate among them; approximately one bird in 25 of these three species excreted salmonellae.

The most frequently isolated serotype was $S$. typhimurium which was found in 18 samples. Seven phage-types of this organism were observed, of which $2 \mathrm{a}$ was the commonest. The other serotypes were S. paratyphi B (phage-type 3a) and S. emek. S. typhi was not encountered.

Rappaport's medium was more efficient than Selenite $F$ in isolating salmonellae from duck droppings. Out of a total number of 20 isolations, five were grown in both media; all the others were isolated in Rappaport's medium only.

TABLE

Incidence and types of salmonellae in wild ducks

\begin{tabular}{|c|c|c|c|c|c|}
\hline \multirow{2}{*}{ Species of duck } & \multicolumn{2}{|c|}{$\begin{array}{c}\text { Number examined } \\
\text { during }\end{array}$} & \multirow{2}{*}{$\begin{array}{l}\text { Number } \\
\text { positive for } \\
\text { salmonellae }\end{array}$} & \multicolumn{2}{|c|}{ Salmonella isolates } \\
\hline & $1968 / 69$ & $1969 / 70$ & & Serotype & Phage-type \\
\hline $\begin{array}{l}\text { Teal } \\
\text { Tufted duck }\end{array}$ & $\begin{array}{r}58 \\
109\end{array}$ & $\begin{array}{l}30 \\
89\end{array}$ & $\begin{array}{r}3 \\
10\end{array}$ & $\begin{array}{l}\text { S. typhimurium } \\
\text { S. typhimurium } \\
\text { S. paratyphi B } \\
\text { S. emek }\end{array}$ & $\begin{array}{l}\mathrm{u} 15,2 \mathrm{a}(2) \\
2 \mathrm{a}(5), \mathrm{u} 218(3) \\
3 \mathrm{a}\end{array}$ \\
\hline Pochard & 79 & 51 & 4 & S. typhimurium & $\begin{array}{l}2 \mathrm{a}, \mathrm{u} 40, \mathrm{w} 195 \\
\mathrm{u} 180\end{array}$ \\
\hline $\begin{array}{l}\text { Species uncertain } \\
\text { Widgeon } \\
\text { Gadwall }\end{array}$ & $\begin{array}{l}34 \\
12 \\
15\end{array}$ & $\begin{array}{l}0 \\
0 \\
0\end{array}$ & $\begin{array}{l}3 \\
0 \\
0\end{array}$ & $\begin{array}{c}\text { S. typhimurium } \\
\ldots \\
\ldots\end{array}$ & $\begin{array}{c}\mathrm{u} 102, \mathrm{u} 165(2) \\
\ldots \\
\ldots\end{array}$ \\
\hline Total & 307 & 170 & 20 & & \\
\hline
\end{tabular}

\section{Discussion}

The frequency of faecal excretion of salmonellae found in this survey of wild ducks is higher than was expected from the post-mortem studies of previous workers. The results, however, are in accord with the recent findings of Windle Taylor (1967) and Farrant et al. (1964) in other species of birds.

Salmonella carriage in birds is usually regarded as transient, but our findings of a frequency of just over 4 per cent. in both winters suggests that a constant proportion of birds harbour salmonellae. The alternative explanation is that constant reinfection takes place during the winter when large numbers of birds flock together.

All the salmonella serotypes isolated are known to cause disease in man; the commonest were $S$. typhimurium, phage-type $2 \mathrm{a}$, and $S$. paratyphi $\mathrm{B}$, phage-type $3 \mathrm{a}$.

The ducks from which these organisms were isolated are winter visitors to this country. They probably summer in Scandinavia and Russia (Spencer, 1966, 1967, 1968), the autumn and spring migrations taking place in easy stages depending on weather conditions and local food supplies. During the winter there is much local movement of birds, and infected birds can, therefore, pollute many tracts of water during the course of a year.

Salmonella excretion into water intended for human use is a very important problem, as shown by a survey for the Metropolitan Water Board (Windle Taylor). The salmonella serotypes recovered from gull faeces overlapped considerably with those found in primary and secondary filtration installations on some reservoirs. It is reasonable to assume that ducks may also contribute to this bacterial contamination.

Our assessment of Rappaport's medium for isolating salmonellae from bird faeces is in accord with the findings of others (Hooper and Jenkins, 1965). The greater recovery rate 
of these organisms when this medium is used may partly explain the wide differences in the published rates of avian salmonellosis.

\section{SUMMARY}

The faecal excretion rate of salmonellae in migratory wild ducks is higher than previous studies would indicate. Examination of 477 duck droppings during the winters of 1968/69 and 1969/70 gave isolation rates of just over 4 per cent. The commonest serotype was $S$. typhimurium; seven different phage-types were found, 2 a being the most frequent.

We wish to thank the Metropolitan Water Board for granting permission to one of us (T. R. M.) to collect material from Barn Elms Reservoir. We would also like to thank Professor H. I. Winner for his help and encouragement in the preparation of this paper; Dr Joan Taylor of the Salmonella Reference Laboratory, Colindale, and Dr E. S. Anderson of the Enteric Reference Laboratory, Colindale, for confirming the identity of the salmonella serotypes and for carrying out the subsequent phage-typing.

\section{REFERENCES}

Cruickshank, J. C., AND Smith, H. W. 1949. Isolation of salmonellae from dogs, cats and pigeons. Br. Med. J., 2, 1254.

Faddoul, G. P., Fellows, G. W., ANd Baird, J. 1966. A survey on the incidence of salmonellae in wild birds. Avian Dis., 10, 89.

Farrant, W. N., Phillips, A. G., ANd Roger, Suzanne M. 1964. Salmonella typhi-murium in London pigeons. Mon. Bull. Minist. Hlth, 23, 231.

HoOPER, W. L., AND JENKINS, H. R. 1965. An evaluation of Rappaport's magnesium chloride/malachite green medium in the routine examination of faeces. J. Hyg., Camb., 63, 491.

JeNNINGS, A. R. 1961. An analysis of 1000 deaths in wild birds. Bird Study, 8, 25.

KeYMER, I. F. 1958. A survey and review of the causes of mortality in British birds and the significance of wild birds as disseminators of disease. Vet. Rec., 70, 713.

MaCdonald, J. W. 1965. Mortality in wild birds. Bird Study, 12, 181.

NIELSEN, B. B. 1960 . Salmonella typhimurium carriers in seagulls and mallards as a possible source of infection to domestic animals. Nord. Vet-Med., 12, 417.

RAPPAPORT, F., Konforti, N., AND NAVON, BEtTy 1956. A new enrichment medium for certain salmonellae. J. Clin. Path., 9, 261.

SPENCER, R. 1966. Report on bird ringing for 1965. Br. Birds, 59, 441.

SPENCER, R. 1967. Report on bird ringing for 1966. Br. Birds, 60, 429.

SPENCER, R. 1968. Report on bird ringing for 1967. Br. Birds, 61, 477.

Wilson, J. E., AND MACDONALd, J. W. 1967. Salmonella infection in wild birds. Br. Vet. J., 123, 212.

Windle TaYlor, E. 1967. Pollution by gulls. Rep. Metrop. Wat. Bd, no. 42, p. 20. 